\title{
Liquidus Projection and Reaction Scheme of the Co-Al-Nb System
}

\author{
M. Palm, C. He, O. Dovbenko, F. Stein, and J.C. Schuster
}

(Submitted November 29, 2011; in revised form March 21, 2012)

\begin{abstract}
By metallographic observation of the as-cast microstructures, determination of the liquidus temperatures and the temperatures of invariant reactions by differential thermal analysis, and measurement of the compositions of the primary phases and the eutectic residuals by electron probe miroanalysis, a liquidus projection for the Co-Al-Nb system has been established for the first time. The binary Co-Nb intermetallic phases have a large solid solubility for Al and their melting temperatures increase markedly by the addition of Al. The only ternary compound, the Heusler phase $\mathrm{NbCo}_{2} \mathrm{Al}$, melts incongruently at about $1485^{\circ} \mathrm{C}$. By CALPHAD modelling the consistency of the experimental data has been checked. Calculated and experimentally determined temperatures of the invariant reactions are in good agreement and are summarised within a reaction scheme.
\end{abstract}

Keywords CALPHAD, differential thermal analysis (DTA), electron probe microanalysis (EPMA), liquidus surface, microstructure, ternary system

\section{Introduction}

The Co- $\mathrm{Nb}(-\mathrm{Al})$ system is of considerable interest for the basic understanding of the stability of the different polytypes of the Laves phase in dependence on temperature and composition, because all three polytypes of the Laves phase-hexagonal $C 14^{1}$ and $C 36$ and cubic $C 15$ - are stable within the binary $\mathrm{Co}-\mathrm{Nb}$ system. ${ }^{[1,2]} \mathrm{A}$ list of phases that are stable in the Co-Al-Nb system and the binary subsystems at the liquidus together with the invariant reactions involving the liquid is compiled in Table 1. Besides the binary phases a number of ternary compounds have been reported. The $\mathrm{NbCo}_{2} \mathrm{Al}$ Heusler phase first reported by Markiv et al. ${ }^{[4]}$ exists between about 12-25 Nb (all compositions in at.\% except where noted) and 25-35 $\mathrm{Al}^{[5,6]}$ and it is not known whether this phase melts congruently or incongruently. Hunt and $\operatorname{Raman}^{[7]}$ reported a phase at a composition of about 26 $\mathrm{Co}, 20 \mathrm{Al}, 54 \mathrm{Nb}$ whose structure they could not identify exactly but as the x-ray diffraction (XRD) pattern was closely related to that of $\mathrm{Co}_{7} \mathrm{Nb}_{6}$ ( $\mu$ phase; $\mathrm{Fe}_{7} \mathrm{~W}_{6}$-type) they termed the phase $\mu^{\prime}$. The phase was also reported by Burnashova et al. ${ }^{[5]}$

\footnotetext{
${ }^{1}$ Because all three Laves phases nominally have the same stoichiometry of $\mathrm{AB}_{2}$, Strukturbericht designations are chosen to differentiate between these three polytypes.

M. Palm, and F. Stein, Max-Planck-Institut für Eisenforschung GmbH, Postfach 14044440074 Düsseldorf, Germany; C. He, College of Material Science and Engineering, Guangxi University, Daxue Str.100, Nanning 530004 Guangxi, China; O. Dovbenko, MSI, Materials Science International Services $\mathrm{GmbH}$, Industriestrasse 25, 70565 Stuttgart, Germany; J.C. Schuster, AG Neue Materialien, Universität Wien, Währingerstr. 42, 1090 Wien, Austria. Contact e-mail: palm@mpie.de.
}

The hexagonal $C 14$ Laves phase, which is only stable above about $1250{ }^{\circ} \mathrm{C}$ in the binary Co-Nb system, ${ }^{[2]}$ exists in the ternary system within an extended homogeneity range even at much lower temperatures, e.g., at $800{ }^{\circ} \mathrm{C}^{[5,6]}$ Above $1250{ }^{\circ} \mathrm{C}$ the single-phase field of $\mathrm{C} 14$ extends from the binary system to an $\mathrm{Al}$ content of 55 at.\%. ${ }^{[6]}$

Unfortunately, only scarce information on phase equilibria within this system exists and neither a projection of the liquidus surface nor a reaction scheme has been published yet. ${ }^{[8,9]}$ Even the few information about phase equilibria involving the liquid is not unambiguous. Nesterovich et al. ${ }^{[10]}$ found that the eutectic $\alpha-\mathrm{Co}(\mathrm{Al}, \mathrm{Nb})+\mathrm{Co}_{2} \mathrm{Nb}$ (the structural variant of this Laves phase has not been specified) extends somewhat into the ternary system but this finding has explicitly not been accepted in the assessment by Neiva. ${ }^{[8]}$ However, also Haour et al. ${ }^{[11]}$ reported a eutectic at $77.3 \mathrm{Co}, 7.3 \mathrm{Al}, 15.4 \mathrm{Nb}$ at $1240{ }^{\circ} \mathrm{C}$ which they assumed to be $\alpha-\mathrm{Co}(\mathrm{Al}, \mathrm{Nb})+\mathrm{Co}_{2} \mathrm{Nb}$, though the phases have not been identified in their work. The only other information available is that Subramanian and Simmons ${ }^{[12]}$ observed a differential thermal analysis (DTA) signal at $1174{ }^{\circ} \mathrm{C}$ in the Al-rich corner of the system which they associated with the invariant reaction $\mathrm{L}+\mathrm{CoAl} \leftrightarrow \mathrm{NbAl}_{3}+\mathrm{Co}_{2} \mathrm{Al}_{5}$.

The current investigations were performed within the framework of the inter-institutional research project "The Nature of Laves Phases" (http://Laves.mpie.de) which focuses on the systems X-Al-Nb (X = Fe, Co, Cr). Because this investigation concentrates on the different polytypes of the Laves phase, the $\mathrm{Nb}$ - and Al-corner have not been considered in the present work. It is noted that for the $\mathrm{Co}-\mathrm{Al}-\mathrm{Nb}$ system also five isothermal sections between 800 and $1250{ }^{\circ} \mathrm{C}$ have been experimentally determined. ${ }^{[6]}$

\section{Experimental}

Five binary $\mathrm{Co}-\mathrm{Al}$ and 35 ternary alloys were produced from Co (99.95 wt.\%), Al (99.999 wt.\%), and $\mathrm{Nb}$ (99.9 wt.\%) by crucible-free levitation melting. After melting, the alloys 
Table 1 Crystallographic data, melting points and melting behaviour for binary and ternary phases of the Co-Al-Nb system

\begin{tabular}{|c|c|c|c|c|c|c|c|c|}
\hline Phase/Reaction & $\begin{array}{c}\text { Pearson } \\
\text { symbol }\end{array}$ & $\begin{array}{l}\text { Space } \\
\text { group }\end{array}$ & $\begin{array}{c}\text { Structure } \\
\text { type }\end{array}$ & $\begin{array}{c}\text { Strukturbericht } \\
\text { designation }\end{array}$ & $\begin{array}{c}\text { Melting } \\
\text { behaviour }\end{array}$ & $\begin{array}{c}\text { Temperature, } \\
{ }^{\circ} \mathrm{C}\end{array}$ & $\begin{array}{c}\text { Composition } \\
\text { Co-Al-Nb, at. } \%\end{array}$ & References \\
\hline$\alpha \mathrm{Co}$ & $c F 4$ & $F m \overline{3} m$ & $\mathrm{Cu}$ & $A 1$ & $\cdots$ & 1495 & $\cdots$ & [16] \\
\hline$L \leftrightarrow(\mathrm{Co})+\mathrm{CoAl}$ & $\cdots$ & $\cdots$ & $\cdots$ & $\cdots$ & Eutectic & 1400 & $\mathrm{~L}: 81.0-19.0-0$ & [16] \\
\hline CoAl & $c P 2$ & $P m \overline{3} m$ & $\mathrm{CsCl}$ & $B 2$ & Congruent & 1675 & $50-50-0$ & This work \\
\hline $\mathrm{Co}_{2} \mathrm{Al}_{5}$ & $h P 28$ & $P 6_{3} / m m c$ & $\mathrm{Co}_{2} \mathrm{Al}_{5}$ & $D 8_{11}$ & Peritectic & 1188 & $28.6-71.4-0$ & [3] \\
\hline$L+\mathrm{CoAl} \leftrightarrow \mathrm{Co}_{2} \mathrm{Al}_{5}$ & $\cdots$ & $\ldots$ & $\ldots$ & $\cdots$ & Peritectic & 1188 & L: $24.4-75.6-0$ & {$[3]$} \\
\hline $\mathrm{NbAl}_{3}$ & $t I 8$ & $I 4 / m m m$ & $\mathrm{~h}-\mathrm{TiAl}_{3}$ & $\mathrm{DO}_{22}$ & Congruent & 1714 & $0-25-75$ & {$[13]$} \\
\hline$L \leftrightarrow \mathrm{NbAl}_{3}+\mathrm{Nb}_{2} \mathrm{Al}$ & $\cdots$ & $\cdots$ & $\cdots$ & $\cdots$ & Eutectic & 1571 & $0-56.2-43.8$ & {$[13]$} \\
\hline $\mathrm{Nb}_{2} \mathrm{Al}$ & $t P 30$ & $P 4_{2} / m n m$ & $\sigma-\mathrm{CrFe}$ & $D 8_{\mathrm{b}}$ & Peritectic & 1940 & $0-32-68$ & [17] \\
\hline$L+N b_{3} A l \leftrightarrow \mathrm{Nb}_{2} A l$ & $\cdots$ & $\cdots$ & $\cdots$ & $\cdots$ & Peritectic & 1940 & $0-\sim 36-\sim 64$ & [17] \\
\hline $\mathrm{Nb}_{3} \mathrm{Al}$ & $c P 8$ & $\operatorname{Pm} \overline{3} n$ & $\mathrm{Cr}_{3} \mathrm{Si}$ & $A 15$ & Peritectic & 2060 & $0-\sim 22.5-\sim 77.5$ & {$[17]$} \\
\hline$L+(N b) \leftrightarrow \mathrm{Nb}_{3} A l$ & $\cdots$ & $\cdots$ & $\cdots$ & $\cdots$ & Peritectic & 2060 & $0-\sim 28-\sim 72$ & [17] \\
\hline$(\mathrm{Nb})$ & $c 12$ & $\operatorname{Im} \overline{3} m$ & $\mathrm{~W}$ & $A 2$ & $\ldots$ & 2469 & $\ldots$ & {$[17]$} \\
\hline$L \leftrightarrow(\mathrm{Nb})+\mathrm{Co}_{7} \mathrm{Nb}_{6}$ & $\cdots$ & $\cdots$ & $\cdots$ & $\cdots$ & Eutectic & 1364 & $36.7-0-63.3$ & {$[1]$} \\
\hline $\mathrm{Co}_{7} \mathrm{Nb}_{6}(\mu)$ & $h R 13$ & $R \overline{3} m$ & $\mathrm{Fe}_{7} \mathrm{~W}_{6}$ & $D 8_{5}$ & Congruent & 1424 & $48.2-0-51.8$ & {$[1]$} \\
\hline$L \leftrightarrow \mathrm{Co}_{7} \mathrm{Nb}_{6}+\mathrm{Cl} 4$ & $\cdots$ & $\cdots$ & $\ldots$ & $\cdots$ & Eutectic & 1379 & $45.1-0-54.9$ & {$[1,2]$} \\
\hline$L+C 15 \leftrightarrow \mathrm{C} 14$ & $\cdots$ & $\cdots$ & $\cdots$ & $\cdots$ & Peritectic & 1424 & $58-0-42$ & {$[2]$} \\
\hline $\mathrm{NbCo}_{2}(C 14)$ & $h P 12$ & $\mathrm{P6}_{3} / m m c$ & $\mathrm{MgZn}_{2}$ & $C 14$ & Peritectic & 1424 & $63.5-0-36.5$ & [2] \\
\hline $\mathrm{NbCo}_{2}(C 15)$ & $c F 24$ & $F d \overline{3} m$ & $\mathrm{MgCu}_{2}$ & $C 15$ & Congruent & 1484 & $66.7-0-33.3$ & [2] \\
\hline$L+C 15 \leftrightarrow \mathrm{C} 36$ & $\cdots$ & $\ldots$ & $\ldots$ & $\cdots$ & Peritectic & 1264 & $85.5-0-14.5$ & {$[2]$} \\
\hline $\mathrm{NbCo}_{2}(C 36)$ & $h P 24$ & $\mathrm{PG}_{3} / m m c$ & $\mathrm{MgNi}_{2}$ & $C 36$ & Peritectic & 1264 & $75.0-0-25.0$ & {$[2]$} \\
\hline$L \leftrightarrow(\mathrm{Co})+C 36$ & $\cdots$ & $\cdots$ & $\cdots$ & $\cdots$ & Eutectic & 1239 & 86.1-0-13.9 & {$[2]$} \\
\hline $\mathrm{NbCo}_{2} \mathrm{Al}$ (Heusler) & $c F 16$ & $F m \overline{3} m$ & $\mathrm{BiF}_{3}$ or $\left(\mathrm{MnCu}_{2} \mathrm{Al}\right)$ & $L 2_{1}$ & $\ldots$ & $\cdots$ & $\cdots$ & {$[4]$} \\
\hline
\end{tabular}

were drop cast into a cold copper mould of 12 or $22 \mathrm{~mm}$ diameter resulting in rods of about $100-120 \mathrm{~mm}$ length. Another seven ternary alloys were produced by arc melting. The resulting buttons were about $15 \mathrm{~mm}$ in diameter. For further examination the alloys were sectioned by electricaldischarge machining (EDM).

The microstructures of the as-cast alloys were studied in a scanning electron microscope (SEM; Hitachi S-530). Compositions of the primary phases, i.e., those which solidified first from the melt, were measured by energy-dispersive spectrometry (EDS; EDAX CDU LEAP system) attached to the SEM or wavelength-dispersive spectrometry (WDS) on an electron probe microanalyser (JEOL JXA-8100). While primary phases were analysed with a beam of $1 \mu \mathrm{m}$ spot size the beam was widened to 3-10 $\mu \mathrm{m}$ for analysis of fine-scaled eutectics. The overall compositions of the alloys were determined by analysing large areas by SEM-EDS.

Phases were also partly identified by XRD of powders which were produced by crushing parts of a sample in a steel mortar and then sieving out the fraction $<90 \mu \mathrm{m}$. XRD spectra were recorded in the $2 \Theta$ range $20-125^{\circ}$ using monochromatic $\mathrm{CoK} \alpha_{1}$ radiation on a Huber and an Inel diffractometer and $\mathrm{CuK} \alpha$ radiation on a PHILIPS PW-1827 diffractometer.

Liquidus temperatures and those of invariant reactions were determined by DTA (Setaram SETSYS-18 DTA) at a heating rate of $10 \mathrm{~K} / \mathrm{min}$. In some cases, additional measurements with lower heating rates of 2 and $5 \mathrm{~K} / \mathrm{min}$ were carried out. The experiments were performed in alumina crucibles under argon atmosphere (purity 99.999 or 99.9999 vol.\%; in addition adsorbers for oxygen and moisture are employed). The DTA was frequently calibrated using pure elements by which the accuracy of the measurements is $\pm 2 \mathrm{~K}$ up to $1750{ }^{\circ} \mathrm{C}$. For the temperatures of the invariant reactions the onsets during heating were taken. The liquidus temperatures were also determined during heating by taking the last maximum of the DTA curve before it finally returns back to the baseline and comparing these values to the onset during cooling. Only in those cases where the signals in the heating curves could not be resolved unambiguously further results obtained on cooling were consulted in addition.

The consistency of all experimental results was finally checked and a reaction scheme was established by calculating the liquidus surface by CALPHAD modelling with the aid of the Thermo-Calc software package (Thermo-Calc Software AB, version R. 2006; available from http://www.thermocalc.se ). In the present modelling, the thermodynamic parameters for the $\mathrm{Nb}-\mathrm{Al}$ system were taken from Ref 13 , the description of the Co-Al system was provided by Dupin, based on her earlier work, ${ }^{[14]}$ but with an improved model for B2 as (Al,Co, $\mathrm{Va})_{0.5}(\mathrm{Al}, \mathrm{Co}, \mathrm{Va})_{0.5} \mathrm{Va}_{3}$. The thermodynamic parameters for the $\mathrm{Co}-\mathrm{Nb}$ system are from our own work. ${ }^{[15]}$

\section{Results and Discussion}

Table 1 lists all crystallographic information, melting points and melting behavior of the phases that are stable at 
Table 2 Composition of the alloys, temperatures of invariant reactions, and compositions of primary phases and residual eutectics

\begin{tabular}{|c|c|c|c|c|}
\hline $\begin{array}{l}\text { Composition } \\
\text { Al-Nb, at.\% }\end{array}$ & Temperature, ${ }^{\circ} \mathrm{C}$ & Reaction & $\begin{array}{l}\text { Composition } \\
\text { Al-Nb, at.\% }\end{array}$ & Phases/reaction \\
\hline $41.5-0$ & $1630 \pm 3$ & Liquidus & $\cdots$ & CoAl \\
\hline $45.2-0$ & $1661 \pm 3$ & Liquidus & $\cdots$ & CoAl \\
\hline $50.3-0$ & $1675 \pm 3$ & Liquidus & $\cdots$ & CoAl \\
\hline $60.0-0$ & $1620 \pm 3$ & Liquidus & $\cdots$ & $\mathrm{CoAl}$ \\
\hline $70.2-0$ & $1395 \pm 3$ & Liquidus & $\ldots$ & CoAl \\
\hline \multirow[t]{3}{*}{$0.9-37.3$} & $1465 \pm 3$ & Liquidus & $0.7-34.9$ & $C 15$ \\
\hline & 1448 & Peritectic & $\ldots$ & $\mathrm{L}+C 15 \leftrightarrow C 14$ \\
\hline & 1387 & Eutectic & $\cdots$ & $\mathrm{L} \leftrightarrow C 14+\mathrm{Co}_{7} \mathrm{Nb}_{6}$ \\
\hline \multirow[t]{3}{*}{$1.1-24.2$} & 1440 & Liquidus & $0.8-27.1$ & $C 15$ \\
\hline & 1269 & Peritectic & $\cdots$ & $\mathrm{L}+C 15 \leftrightarrow C 36$ \\
\hline & 1238 & Eutectic & $2.2-13.7$ & $\mathrm{~L} \leftrightarrow C 36+(\mathrm{Co})$ \\
\hline \multirow[t]{2}{*}{$1.5-34.5(\mathrm{a})$} & $1481 \pm 5$ & Liquidus & $\ldots$ & $C 15$ \\
\hline & 1445 & Peritectic & $\ldots$ & $\mathrm{L}+C 15 \leftrightarrow C 14$ \\
\hline \multirow[t]{3}{*}{$2.0-33.0(a)$} & 1478 & Liquidus & $\cdots$ & $C 15$ \\
\hline & 1455 & Peritectic & $\cdots$ & $\mathrm{L}+C 15 \leftrightarrow C 14$ \\
\hline & 1390 & Eutectic & $\ldots$ & $\mathrm{L} \leftrightarrow C 14+\mathrm{Co}_{7} \mathrm{Nb}_{6}$ \\
\hline \multirow[t]{2}{*}{$2.0-40.0$} & $1454 \pm 3$ & Liquidus & $3.0-35.8$ & $C 14$ \\
\hline & 1390 & Eutectic & $\ldots$ & $\mathrm{L} \leftrightarrow C 14+\mathrm{Co}_{7} \mathrm{Nb}_{6}$ \\
\hline \multirow[t]{3}{*}{$2.2-20.6$} & $1408 \pm 10$ & Liquidus & $1.5-27.5$ & $C 15$ \\
\hline & 1270 & Peritectic & $\ldots$ & $\mathrm{L}+C 15 \leftrightarrow C 36$ \\
\hline & 1238 & Eutectic & $3.4-13.6$ & $\mathrm{~L} \leftrightarrow C 36+(\mathrm{Co})$ \\
\hline \multirow[t]{3}{*}{$2.3-27.3$} & $1469 \pm 4$ & Liquidus & $\ldots$ & $C 15$ \\
\hline & 1276 & Peritectic & $\ldots$ & $\mathrm{L}+\boldsymbol{C 1 5} \leftrightarrow C 36$ \\
\hline & 1229 & Eutectic & $\ldots$ & $\mathrm{L} \leftrightarrow C 36+(\mathrm{Co})$ \\
\hline $3.0-30.0(a)$ & $1483 \pm 6$ & Liquidus & $\ldots$ & $C 15$ \\
\hline \multirow[t]{2}{*}{$3.1-38.1$} & $1461 \pm 5$ & Liquidus & $3.9-35.4$ & $C 14$ \\
\hline & 1394 & Eutectic & $\cdots$ & $\mathrm{L} \leftrightarrow C 14+\mathrm{Co}_{7} \mathrm{Nb}_{6}$ \\
\hline $4.0-33.0(a)$ & 1475 & Liquidus & $\ldots$ & Laves $(C 15 ?)$ \\
\hline \multirow[t]{3}{*}{$4.8-29.2$} & $1476 \pm 5$ & Liquidus & $4.0-30.5$ & $C 15$ \\
\hline & 1323 & Peritectic & $\ldots$ & $\mathrm{L}+\boldsymbol{C 1 5} \leftrightarrow \boldsymbol{C 3 6}$ \\
\hline & 1270 & Eutectic & $\ldots$ & $\mathrm{L} \leftrightarrow C 36+\mathrm{CoAl}$ \\
\hline $6.0-33.0(a)$ & 1475 & Liquidus & $\ldots$ & Laves $(C 15$ or $C 14)$ \\
\hline $8.0-33.0(a)$ & 1477 & Liquidus & $\ldots$ & Laves $(C 15$ or $C 14)$ \\
\hline \multirow[t]{4}{*}{$9.4-28.2$} & $1467 \pm 3$ & Liquidus & $8.7-30.8$ & $C 14$ \\
\hline & $1338(\mathrm{c})$ & Peritectic & $\ldots$ & $\mathrm{L}+\boldsymbol{C 1 4} \leftrightarrow C 36$ \\
\hline & $\sim 1330$ & Peritectic & $\ldots$ & $\mathrm{L}+C 36 \leftrightarrow \mathrm{NbCo}_{2} \mathrm{Al}$ \\
\hline & $1295(d)$ & U-Type & $\ldots$ & $\mathrm{L}+\mathrm{NbCo}_{2} \mathrm{Al} \leftrightarrow C 36+\mathrm{CoAl}$ \\
\hline \multirow[t]{2}{*}{$9.7-42.8$} & $1470 \pm 2$ & Liquidus & $14.4-36.8$ & $C 14$ \\
\hline & 1422 & Eutectic & $\ldots$ & $\mathrm{L} \leftrightarrow C 14+\mathrm{Co}_{6} \mathrm{Nb}_{7}$ \\
\hline \multirow[t]{4}{*}{$9.8-26.1$} & $1451 \pm 2$ & Liquidus & $8.3-29.8$ & $C 14$ \\
\hline & $\sim 1339$ & Peritectic & $\ldots$ & $\mathrm{L}+\boldsymbol{C 1 4} \leftrightarrow C 36$ \\
\hline & 1324 & Peritectic & $\cdots$ & $\mathrm{L}+C 36 \leftrightarrow \mathrm{NbCo}_{2} \mathrm{Al}$ \\
\hline & $\sim 1295(\mathrm{~d})$ & U-Type & $\ldots$ & $\mathrm{L}+\mathrm{NbCo}_{2} \mathrm{Al} \leftrightarrow C 36+\mathrm{CoAl}$ \\
\hline \multirow[t]{2}{*}{$9.9-30.5$} & 1480 & Liquidus & $10.0-30.7$ & $\mathrm{C} 14$ \\
\hline & 1384(d) & Peritectic & $\ldots$ & $\mathrm{L}+\mathrm{C14} \leftrightarrow \mathrm{Co}_{2} \mathrm{AlNb}$ \\
\hline \multirow[t]{3}{*}{$10.0-10.5$} & 1280 & Liquidus & $10.9-4.1$ & (Co) \\
\hline & 1226 & Eutectic & $9.4-12.8$ & $\mathrm{~L} \leftrightarrow(\mathbf{C o})+C 36$ \\
\hline & 1220 & Tern. Eutectic & $\cdots$ & $\mathrm{L} \leftrightarrow(\mathbf{C o})+\mathrm{CoAl}+C 36$ \\
\hline \multirow[t]{4}{*}{$10.0-25.5$} & 1446 & Liquidus & $8.5-29.0$ & $C 14$ \\
\hline & 1325 & Peritectic & $\ldots$ & $\mathrm{L}+\boldsymbol{C 1 4} \leftrightarrow C 36$ \\
\hline & 1303 & Eutectic & $21.0-14.5$ & $\mathrm{~L} \leftrightarrow \mathrm{CoAl}+C 36$ \\
\hline & $1295(\mathrm{~d})$ & U-Type & $\ldots$ & $\mathrm{L}+\mathrm{NbCo}_{2} \mathrm{Al} \leftrightarrow C 36+\mathrm{CoAl}$ \\
\hline
\end{tabular}


Table 2 Continued

\begin{tabular}{|c|c|c|c|c|}
\hline $\begin{array}{l}\text { Composition } \\
\text { Al-Nb, at. } \%\end{array}$ & Temperature, ${ }^{\circ} \mathrm{C}$ & Reaction & $\begin{array}{l}\text { Composition } \\
\text { Al-Nb, at. } \%\end{array}$ & Phases/reaction \\
\hline \multirow[t]{4}{*}{$10.1-20.1$} & 1408 & Liquidus & $6.4-26.9$ & $C 15$ \\
\hline & 1320 & Peritectic & $\ldots$ & $\mathrm{L}+C 15 \leftrightarrow C 36$ \\
\hline & 1234 & Eutectic & $19.9-12.8$ & $\mathrm{~L} \leftrightarrow \mathrm{CoAl}+C 36$ \\
\hline & 1220 & Tern. Eutectic & $10.5-12.2$ & $\mathrm{~L} \leftrightarrow(\mathrm{Co})+\mathrm{CoAl}+\mathrm{C36}$ \\
\hline \multirow[t]{2}{*}{$10.7-36.0$} & 1487 & Liquidus & $12.4-34.3$ & $C 14$ \\
\hline & 1412 & Eutectic & $\cdots$ & $\mathrm{L} \leftrightarrow C 14+\mathrm{Co}_{7} \mathrm{Nb}_{6}$ \\
\hline $13.0-32.0(\mathrm{a})$ & 1488 & Liquidus & $\cdots$ & $C 14$ \\
\hline \multirow[t]{2}{*}{$13.9-10.4$} & 1260 & Liquidus & $23.7-5.4$ & CoAl \\
\hline & 1220 & Tern. Eutectic & $11.3-12.1$ & $\mathrm{~L} \leftrightarrow(\mathrm{Co})+\mathrm{CoAl}+C 36$ \\
\hline \multirow[t]{2}{*}{$19.9-33.2$} & $1535 \pm 5$ & Liquidus & $20.2-33.2$ & $C 14$ \\
\hline & n.d. & Eutectic & $\cdots$ & $\mathrm{L} \leftrightarrow C 14+\mathrm{NbCo}_{2} \mathrm{Al}$ \\
\hline \multirow[t]{3}{*}{$20.4-48.3$} & 1551 & Liquidus & $22.4-48.0$ & $\mathrm{Co}_{7} \mathrm{Nb}_{6}$ \\
\hline & $1495 \pm 5$ & $?$ & $\ldots$ & Formation impurity phase $\mathrm{X}$ ? \\
\hline & 1483 & $?$ & $\cdots$ & Reaction of X? \\
\hline \multirow[t]{3}{*}{$21.0-59.4(b)$} & $1611 \pm 10$ & Liquidus & $\cdots$ & $\mathrm{Nb}_{2} \mathrm{Al}$ \\
\hline & 1496 & Peritectic & $\cdots$ & $\mathrm{L}+\mathrm{Nb}_{2} \mathrm{Al} \leftrightarrow \mathrm{Co}_{7} \mathrm{Nb}_{6}$ \\
\hline & 1476 & U-type? & $\cdots$ & $\mathrm{L}+\mathrm{Nb}_{2} \mathrm{Al} \leftrightarrow(\mathrm{Nb})+\mathrm{Co}_{7} \mathrm{Nb}_{6} ?$ \\
\hline \multirow[t]{3}{*}{$24.2-42.0$} & 1580 & Liquidus & $30.6-36.6$ & $C 14$ \\
\hline & $\sim 1510$ & Peritectic & $\ldots$ & $\mathrm{L}+C 14 \leftrightarrow \mathrm{Co}_{7} \mathrm{Nb}_{6}$ \\
\hline & 1500 & $?$ & $\cdots$ & Formation impurity phase $\mathrm{X}$ ? \\
\hline \multirow[t]{2}{*}{$24.9-48.9$} & $1548 \pm 15$ & Liquidus & $27.5-46.2$ & $\mathrm{Co}_{7} \mathrm{Nb}_{6}$ \\
\hline & 1488 & Eutectic & $\cdots$ & $\mathrm{L} \leftrightarrow(\mathrm{Nb})+$ impurity phase $\mathrm{X}$ \\
\hline \multirow[t]{2}{*}{$25.0-60.0(\mathrm{a}, \mathrm{b})$} & $>1670$ & Liquidus & $28.7-64.8$ & $\mathrm{Nb}_{2} \mathrm{Al}$ \\
\hline & 1565 & Peritectic & $\cdots$ & $\mathrm{L}+\mathrm{Nb}_{2} \mathrm{Al} \leftrightarrow \mathrm{Co}_{7} \mathrm{Nb}_{6}$ \\
\hline \multirow[t]{3}{*}{$25.1-25.2$} & $1495 \pm 10$ & Liquidus & $24.4-31.8$ & $C 14$ \\
\hline & 1471 & Eutectic & $\cdots$ & $\mathrm{L} \leftrightarrow C 14+\mathrm{NbCo}_{2} \mathrm{Al}$ \\
\hline & n.d. & U-type & $\cdots$ & $\mathrm{L}+C 14 \leftrightarrow \mathrm{NbCo}_{2} \mathrm{Al}+C 36$ \\
\hline \multirow[t]{8}{*}{$26.1-15.6$} & $1464 \pm 6$ & Liquidus & $35.1-10.2$ & $\mathrm{CoAl}$ \\
\hline & $\sim 1450$ & Peritectic & $\cdots$ & $\mathrm{L}+\mathrm{CoAl} \leftrightarrow \mathrm{NbCo}_{2} \mathrm{Al}$ \\
\hline & 1304 & Eutectic & $\cdots$ & $\mathrm{L} \leftrightarrow \mathrm{NbCo}_{2} \mathrm{Al}+C 36$ \\
\hline & 1294 & U-type & $\cdots$ & $\mathrm{L}+\mathrm{NbCo}_{2} \mathrm{Al} \leftrightarrow C 36+\mathrm{CoAl}$ \\
\hline & $\cdots$ & $\cdots$ & $26.9-16.0$ & $\mathrm{NbCo}_{2} \mathrm{Al}$ \\
\hline & $\cdots$ & $\cdots$ & $6.7-24.0$ & $C 36$ (according to composition) \\
\hline & $\cdots$ & $\cdots$ & $25.8-6.6$ & $\mathrm{CoAl}$ \\
\hline & $\sim 1215$ & Tern. Eutectic & $10.4-11.0$ & $\mathrm{~L} \leftrightarrow(\mathrm{Co})+\mathrm{CoAl}+C 36$ \\
\hline \multirow[t]{2}{*}{$28.7-35.4$} & 1610 & Liquidus & $32.8-34.3$ & $C 14$ \\
\hline & n.d. & Peritectic & $\cdots$ & $\mathrm{L}+C 14 \leftrightarrow \mathrm{Co}_{7} \mathrm{Nb}_{6}$ \\
\hline \multirow[t]{4}{*}{$33.3-48.8$} & $1610 \pm 10$ & Liquidus & $30.2-65.1$ & $\mathrm{Nb}_{2} \mathrm{Al}$ \\
\hline & $1595 \pm 10$ & Eutectic & $36.8-47.0$ & $\mathrm{~L} \leftrightarrow \mathrm{Nb}_{2} \mathrm{Al}+C 14$ \\
\hline & 1578 & Tern. Peritectic & & $\mathrm{L}+\mathrm{Nb}_{2} \mathrm{Al}+C 14 \leftrightarrow \mathrm{Co}_{7} \mathrm{Nb}_{6}$ \\
\hline & & & $31.8-47.2$ & $\mathrm{Co}_{7} \mathrm{Nb}_{6}$ \\
\hline \multirow[t]{2}{*}{$34.4-25.4$} & 1568 & Liquidus & $34.2-33.2$ & $C 14$ \\
\hline & 1494 & Eutectic & $35.0-20.3$ & $\mathrm{~L} \leftrightarrow \mathrm{CoAl}+C 14$ \\
\hline \multirow[t]{2}{*}{$39.3-35.1$} & $1670 \pm 5$ & Liquidus & $41.2-34.0$ & $C 14$ \\
\hline & n.d. & Peritectic & $\cdots$ & $\mathrm{L}+C 14 \leftrightarrow \mathrm{Co}_{7} \mathrm{Nb}_{6}$ \\
\hline \multirow[t]{2}{*}{$39.7-15.9$} & 1545 & Liquidus & $44.5-6.1$ & $\mathrm{CoAl}$ \\
\hline & 1493 & Eutectic & $35.6-21.5$ & $\mathrm{~L} \leftrightarrow \mathrm{CoAl}+C 14$ \\
\hline \multirow[t]{3}{*}{$46.2-20.7$} & $\sim 1580$ & Liquidus & $\cdots$ & $C 14$ \\
\hline & 1496 & Eutectic & $48.2-14.3$ & $\mathrm{~L} \leftrightarrow \mathrm{CoAl}+C 14$ \\
\hline & $1319(d)$ & U-Type & $\cdots$ & $\mathrm{L}+C 14 \leftrightarrow \mathrm{NbAl}_{3}+\mathrm{CoAl}$ \\
\hline \multirow[t]{2}{*}{$48.7-35.6$} & $1680 \pm 5$ & Liquidus & $49.5-33.7$ & $C 14$ \\
\hline & 1623 & Eutectic & $44.6-46.8$ & $\mathrm{~L} \leftrightarrow \mathrm{Nb}_{2} \mathrm{Al}+C 14$ \\
\hline
\end{tabular}


Section I: Basic and Applied Research

Table 2 Continued

\begin{tabular}{|c|c|c|c|c|}
\hline $\begin{array}{l}\text { Composition } \\
\text { Al-Nb, at.\% }\end{array}$ & Temperature, ${ }^{\circ} \mathrm{C}$ & Reaction & $\begin{array}{l}\text { Composition } \\
\text { Al-Nb, at.\% }\end{array}$ & Phases/reaction \\
\hline \multirow[t]{3}{*}{$60.0-23.0(a)$} & $>1600$ & Liquidus & $\cdots$ & $C 14$ \\
\hline & 1492 & $?$ & $\ldots$ & $?$ \\
\hline & 1322 & U-Type & $\cdots$ & $\mathrm{L}+C 14 \leftrightarrow \mathrm{NbAl}_{3}+\mathrm{CoAl}$ \\
\hline \multirow[t]{4}{*}{$60.0-25.0(a)$} & 1633 & Liquidus & $52.7-32.4$ & $C 14$ \\
\hline & 1541 & Eutectic & $\ldots$ & $\mathrm{L} \leftrightarrow C 14+\mathrm{NbAl}_{3}$ \\
\hline & 1495 & $?$ & $\ldots$ & $?$ \\
\hline & 1322 & U-Type & $62.5-10.0$ & $\mathrm{~L}+C 14 \leftrightarrow \mathrm{NbAl}_{3}+\mathrm{CoAl}$ \\
\hline \multirow[t]{2}{*}{$66.1-32.8$} & 1690 & Liquidus & $73.9-25.8$ & $\mathrm{NbAl}_{3}$ \\
\hline & 1553 & Tern. Eutectic & $55.1-42.1$ & $\mathrm{~L} \leftrightarrow \mathrm{NbAl}_{3}+C 14+\mathrm{Nb}_{2} \mathrm{Al}$ \\
\hline \multirow[t]{4}{*}{$68.5-10.6$} & 1420 & Liquidus & $73.4-24.9$ & $\mathrm{NbAl}_{3}$ \\
\hline & 1322 & U-Type & $62.8-9.1$ & $\mathrm{~L}+C 14 \leftrightarrow \mathrm{NbAl}_{3}+\mathrm{CoAl}$ \\
\hline & 1174 & U-Type & $\cdots$ & $\mathrm{L}+\mathrm{CoAl} \leftrightarrow \mathrm{Co}_{2} \mathrm{Al}_{5}+\mathrm{NbAl}_{3}$ \\
\hline & $\cdots$ & $\cdots$ & $71.0-0.2$ & $\mathrm{Co}_{2} \mathrm{Al}_{5}$ \\
\hline
\end{tabular}

Compositions were established by EPMA and SEM-EDS and temperatures were measured by DTA. Phases given in bold have additionally been identified by XRD. The uncertainty in the determination is $\pm 1{ }^{\circ} \mathrm{C}$ if not stated otherwise. n.d. phases observed but reaction not detected by DTA

(a) Intended composition
(b) Inhomogeneous alloy
(c) Only observed on cooling
(d) Not observed on 1st heating

the liquidus in the Co-Al-Nb system in the composition range under consideration. For the Co-Al system the data of McAllister ${ }^{[16]}$ are accepted except that the current DTA data show that the melting point of $\mathrm{CoAl}$ is at $1675^{\circ} \mathrm{C}$. The $\mathrm{Al}-\mathrm{Nb}$ system is adopted from Ref 17 except for the melting point of $\mathrm{NbAl}_{3}$ and the temperature and the composition of the eutectic $\mathrm{L} \leftrightarrow \mathrm{NbAl}_{3}+\mathrm{Nb}_{2} \mathrm{Al}$ which have been recently experimentally measured and assessed, respectively, by Witusiewicz et al. ${ }^{[13]}$ The Co-Nb system has been re-investigated within the scope of the present project ${ }^{[2,15]}$ except for the $\mathrm{Nb}$-rich part which is adopted from the assessment by Hari Kumar et al. ${ }^{[1]}$ The compositions of the investigated alloys, of the primary phase, i.e., the phase that formed first from the melt, and of the eutectics measured by SEM-EDS and electron probe miroanalysis (EPMA), as well as liquidus temperatures and temperatures of the invariant reactions determined by DTA are summarised in Table 2 . Figure 1 shows a number of micrographs of samples which are decisive for establishing the liquidus projection. The liquidus projection itself is shown in Fig. 2. Isotherms shown in Fig. 2 have been constructed on the basis of experimental information.

The prominent feature of the liquidus surface is the large area of primary solidification of the C14-type Laves phase which "cuts off" those of the C15- and C36-types. By adding $\mathrm{Al}$ to $\mathrm{Co}-\mathrm{Nb}$ the melting temperature of the $C 14$ Laves phase increases from $1424{ }^{\circ} \mathrm{C}$ in the binary system to about $1700{ }^{\circ} \mathrm{C}$. The exact composition of the maximum melting temperature has not been established, but the melting temperatures of alloys Co-39.3Al-35.1 $\mathrm{Nb}$ $\left(1670{ }^{\circ} \mathrm{C}\right)$ and $\mathrm{Co}-48.7 \mathrm{Al}-35.6 \mathrm{Nb}\left(1680{ }^{\circ} \mathrm{C}\right)$ indicate that this maximum may be located at about 45 at. $\% \mathrm{Al}$ and
33.3 at.\% $\mathrm{Nb}$. In the binary $\mathrm{Co}-\mathrm{Nb}$ system the $C 15$ Laves phase is stable at the stoichiometric composition for the Laves phase of $\mathrm{Co}-33.3 \mathrm{Nb}\left(\mathrm{NbCo}_{2}\right)$ while the C14-type Laves phase is only found at off-stoichiometric compositions. By alloying with $\mathrm{Al}$, the primary phase changes from $C 15$ to $C 14$ at the stoichiometric composition when about 5 at.\% $\mathrm{Al}$ are added. This value is in excellent agreement with that reported by von Keitz and Sauthoff. ${ }^{[18]}$. Due to the high melting temperatures of the $C 15$ and $C 14$ Laves phases and of $\mathrm{NbAl}_{3}$ a ridge exists on the ternary liquidus surface between the $\mathrm{Co}-\mathrm{Nb}$ and the $\mathrm{Al}-\mathrm{Nb}$ system. Consequently the monovariant reactions which cross this ridge show a maximum. For the peritectic reaction $\mathrm{L}+C 15 \leftrightarrow C 14$ this maximum is at about $1475{ }^{\circ} \mathrm{C}\left(\mathrm{M}_{4}\right.$ in Fig. 2 and in the reaction scheme in Fig. 4), i.e., at a considerably lower temperature than that of about $1540{ }^{\circ} \mathrm{C}$ given in Ref 18 . For the eutectic reaction $\mathrm{L} \leftrightarrow C 14+\mathrm{NbAl}_{3}$ the temperature of the maximum $\left(\mathrm{M}_{2}\right)$ is estimated from the form of the isotherms to be at about $1650{ }^{\circ} \mathrm{C}$. Like the $C 14$ Laves phase the $\mu$ phase $\mathrm{Co}_{7} \mathrm{Nb}_{6}$ can dissolve large amounts of $\mathrm{Al}$ whereby it is also stabilized to higher temperatures. From $1424{ }^{\circ} \mathrm{C}$ in the binary system the melting point increases up to about $1578{ }^{\circ} \mathrm{C}$ in the ternary system.

Figure 1(a) shows the as-cast microstructure of Co-10.1Al-20.1 Nb. The composition of the alloy lies within the primary field of $C 15$ (Fig. 2) which starts to solidify from the melt at $1408{ }^{\circ} \mathrm{C}$ (Table 2). On cooling the composition of the remaining melt becomes leaner in $\mathrm{Nb}$ and when it crosses the monovariant line $\mathrm{p}_{4}-\mathrm{P}_{3}$ (Fig. 2) at $1320{ }^{\circ} \mathrm{C}, C 36$ forms peritectically by the reaction $\mathrm{L}+C 15$ $\leftrightarrow C 36$. Through formation of $C 36$ on further cooling the melt becomes further depleted in $\mathrm{Nb}$ until it reaches the 

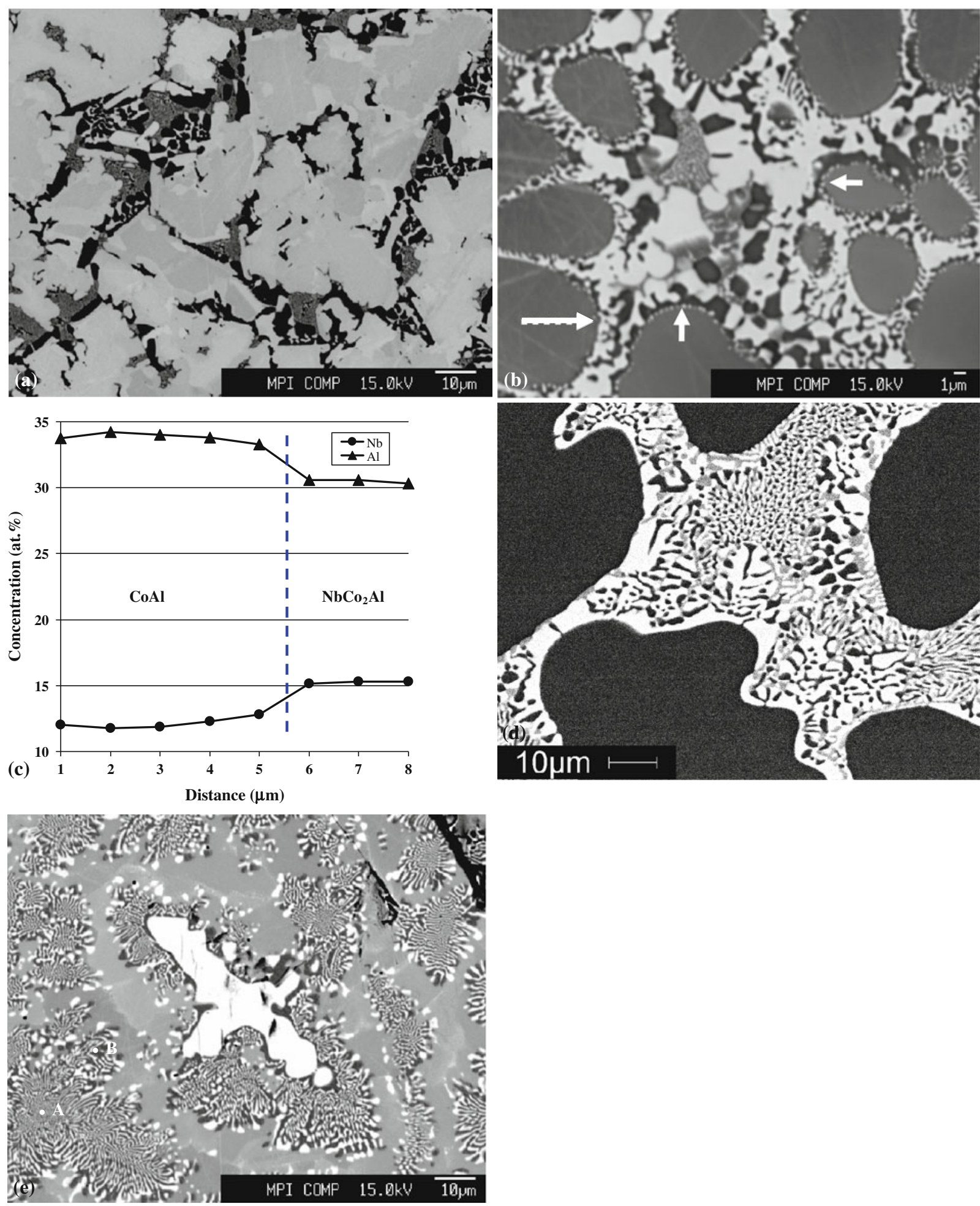

Fig. 1 Back-scattered electron micrographs of the microstructures of as-cast alloys. (a) Co-10.1Al-20.1Nb; primary phase: $C 15$ (grey); peritectically formed phase: $C 36$ (light grey): coarse eutectic: $\mathrm{CoAl}+C 36$; fine eutectic: $\mathrm{CoAl}+C 36+(\mathrm{Co})\left(\mathrm{E}_{2}\right)$. (b) $\mathrm{Co}-26.1 \mathrm{Al}-$ $15.6 \mathrm{Nb}$; primary phase $=$ core of the rounded grains: $\mathrm{CoAl}$ (grey), peritectic $=$ outer part of the rounded grains: $\mathrm{NbCo} \mathrm{Al}_{2}(\mathrm{grey})$; fine $C 36$ (white; marked by solid arrows); coarse eutectic: CoAl (black) $+C 36$ (white); fine-scaled eutectic: $(\mathrm{Co})+\mathrm{CoAl}+C 36\left(\mathrm{E}_{2}\right)$. The dotted arrow denotes the position and direction of the EPMA profile shown in (c). (c) EPMA profile measured from the middle (left side) to the rim (right side) of the rounded grain in (b). Because the Co concentration stays about constant it is not shown. (d) Co-66.1Al-32.8Nb; primary phase: $\mathrm{NbAl}_{3}$ (dark grey); eutectic $\mathrm{E}_{1}$ : $C 14$ (light grey) $+\mathrm{Nb}_{2} \mathrm{Al}$ (white) $+\mathrm{NbAl}_{3}$ (dark grey). (e) Co-33.3Al-48.8Nb; white (primary phase): $\mathrm{Nb}_{2} \mathrm{Al}$; eutectic: $\mathrm{Nb}_{2} \mathrm{Al}$ (white) $+C 14$ (dark); grey: $\mu \mathrm{Co}_{7} \mathrm{Nb}_{6}$ 
(a)
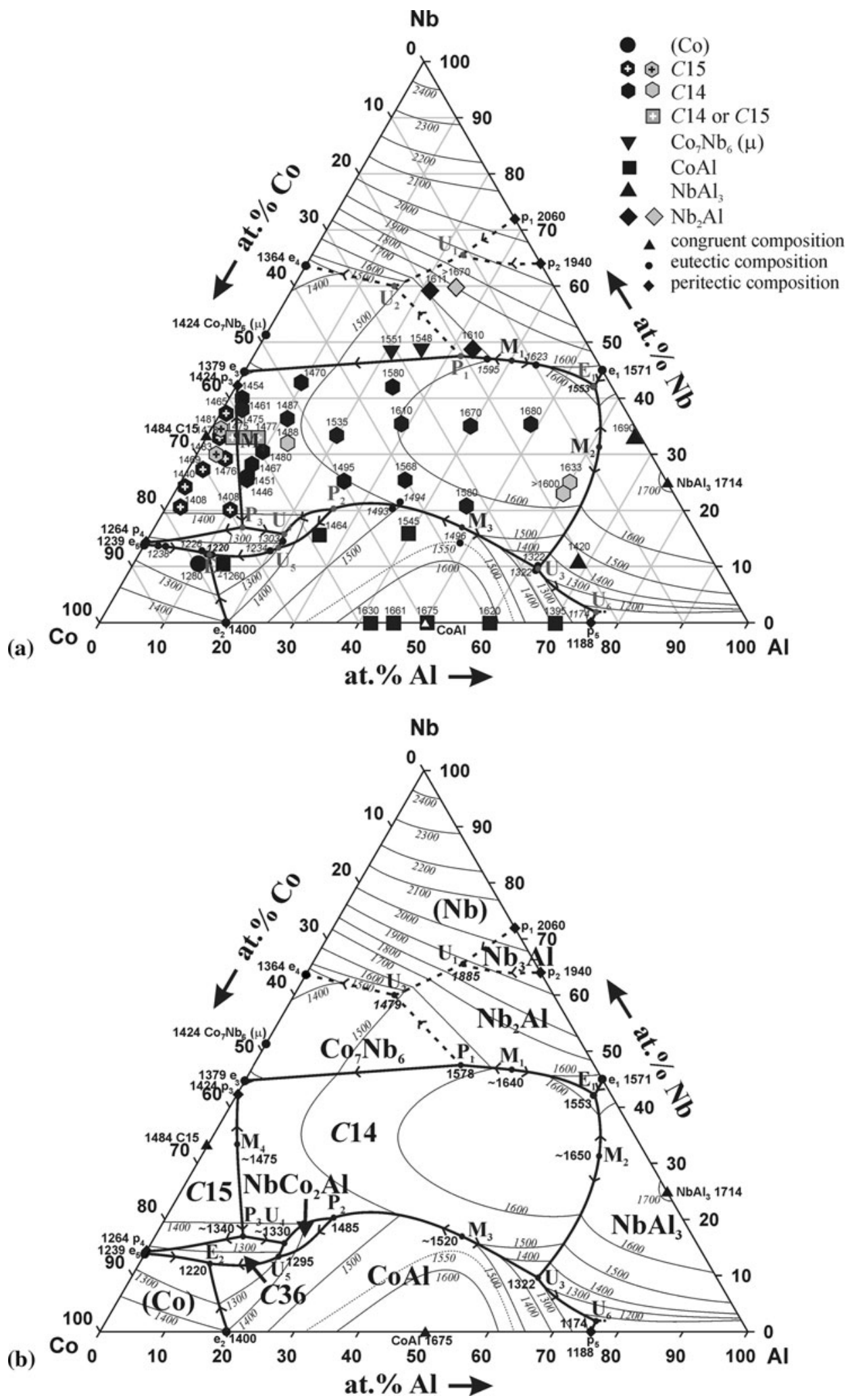

Fig. 2 Experimentally determined liquidus projection of the Co-Al-Nb system. (a) Compositions of the alloys, primary phases, and liquidus temperatures measured by DTA. Large black symbols indicate analysed compositions of the alloys while grey symbols indicate intended compositions. Isotherms have been constructed on the basis of experimental information. (b) Areas of primary crystallisation and established temperatures for the invariant reactions. The temperatures for the invariant reactions $U_{1}$ and $U_{2}$ given in italics are calculated values as they have not been observed experimentally 
monovariant line $\mathrm{E}_{2}-\mathrm{U}_{5}$ at $1234{ }^{\circ} \mathrm{C}$. This line is the eutectic trough $\mathrm{L} \leftrightarrow \mathrm{CoAl}+C 36$ and the corresponding two-phase structure surrounds the coarse $C 15 / C 36$ grains (Fig. 1a). The composition of the melt follows the eutectic trough until at $1220{ }^{\circ} \mathrm{C}$ the ternary eutectic $\mathrm{E}_{2}$ is reached where the residual melt solidifies according to $\mathrm{L} \leftrightarrow(\mathrm{Co})+$ $\mathrm{CoAl}+C 36$ which yields the fine-scaled eutectic in Fig. 1(a). The as-cast microstructure shown in Fig. 1(b) (Co-26.1Al-15.6Nb) was generated by the following solidification sequence: Solidification of primary $\mathrm{CoAl}$ $\left(1464{ }^{\circ} \mathrm{C}\right)$ is followed by peritectic formation of $\mathrm{NbCo}_{2} \mathrm{Al}$ after the melt has reached the monovariant line $\mathrm{U}_{5}-\mathrm{P}_{2}$ at about $1450{ }^{\circ} \mathrm{C}$. The presence of $\mathrm{NbCo}_{2} \mathrm{Al}$ is not visible in the micrograph (Fig. 1b) but only becomes discernible through EPMA (Fig. 1c). At $1304{ }^{\circ} \mathrm{C}$ the melt reaches the eutectic trough $\mathrm{U}_{4}-\mathrm{U}_{5} \mathrm{~L} \leftrightarrow \mathrm{NbCo}_{2} \mathrm{Al}+C 36$. This reaction is only discernible in Fig. 1(b) by the small rim of tiny $C 36$ precipitates which surround the coarse $\mathrm{CoAl} / \mathrm{NbCo}_{2} \mathrm{Al}$ grains. The coarse 2-phase $\mathrm{CoAl}+C 36$ forms at $1294{ }^{\circ} \mathrm{C}$ through the invariant reaction $\mathrm{L}+\mathrm{NbCo}_{2} \mathrm{Al} \leftrightarrow C 36+\mathrm{CoAl}$ $\left(\mathrm{U}_{5}\right)$ and the last melt again solidifies at $\mathrm{E}_{2}$. The ternary eutectic $\mathrm{E}_{2}$ which is also observed in alloys Co-10.0Al$10.5 \mathrm{Nb}$ and $\mathrm{Co}-13.9 \mathrm{Al}-10.4 \mathrm{Nb}$ occurs at $1220{ }^{\circ} \mathrm{C}$ at the composition $77 \mathrm{Co}, 11 \mathrm{Al}, 12 \mathrm{Nb}$. Presumably this is the eutectic that has been reported by Haour et al. ${ }^{[11]}$ before (77.3 Co, 7.3 Al, 15.4 Nb at $1240{ }^{\circ} \mathrm{C}$ ). There are three more invariant reactions in the Co corner, namely $\mathrm{P}_{3} \sim 1340{ }^{\circ} \mathrm{C}$ : $\mathrm{L}+C 15+C 14 \leftrightarrow C 36, \mathrm{U}_{4} \sim 1330{ }^{\circ} \mathrm{C}: \mathrm{L}+C 14 \leftrightarrow C 36+$ $\mathrm{NbCo}_{2} \mathrm{Al} ; \mathrm{U}_{5} 1295^{\circ} \mathrm{C}: \mathrm{L}+\mathrm{NbCo}_{2} \mathrm{Al} \leftrightarrow \mathrm{CoAl}+C 36$. The composition and temperature of the ternary peritectic reaction $\mathrm{P}_{3}$ are estimated from (a) the course of the monovariant line $\mathrm{L}+C 15 \leftrightarrow C 14$ which according to the results of the numerous alloys investigated within this composition range is a more or less vertical line in Fig. 2(a); (b) the temperatures observed for the monovariant reaction $\mathrm{L}+C 15 \leftrightarrow C 36$ in the alloys Co-1.1Al-24.2Nb $\left(1269^{\circ} \mathrm{C}\right)$, Co-2.2Al-20.6 Nb $\left(1270{ }^{\circ} \mathrm{C}\right), \mathrm{Co}-2.3 \mathrm{Al}-27.3 \mathrm{Nb}\left(1276{ }^{\circ} \mathrm{C}\right)$, $\mathrm{Co}-4.8 \mathrm{Al}-29.2 \mathrm{Nb} \quad\left(1323^{\circ} \mathrm{C}\right)$ and $\mathrm{Co}-10.1 \mathrm{Al}-20.1 \mathrm{Nb}$ $\left(1320^{\circ} \mathrm{C}\right)$ which increases with increasing $\mathrm{Al}$ content, indicating that the temperature for $\mathrm{P}_{3}$ must be above $1323{ }^{\circ} \mathrm{C}$; and (c) the temperatures observed for the monovariant reaction $\mathrm{L}+C 14 \leftrightarrow C 36$ for alloys Co-9.4Al$28.2 \mathrm{Nb} \quad\left(1338^{\circ} \mathrm{C}\right), \quad \mathrm{Co}-9.8 \mathrm{Al}-26.1 \mathrm{Nb} \quad\left(\sim 1339{ }^{\circ} \mathrm{C}\right)$ and Co-10.0Al-25.5 Nb $\left(1325^{\circ} \mathrm{C}\right)$ which decreases with increasing $\mathrm{Al}$ content, indicating that the temperature for $\mathrm{P}_{3}$ must be above $\sim 1339{ }^{\circ} \mathrm{C}$. Because the melting temperature of the C36 Laves phase increases when $\mathrm{Al}$ is added, the temperature of $1340{ }^{\circ} \mathrm{C}$ at the peritectic $\mathrm{P}_{3}$ corresponds to the maximum melting point of $C 36$ in the $\mathrm{Co}-\mathrm{Al}-\mathrm{Nb}$ system, which is about $80^{\circ} \mathrm{C}$ higher than in the binary system. There is no direct evidence for the temperature and composition of $\mathrm{U}_{4}$. While the composition of this invariant reaction can only be estimated, the temperature must lie in between that of $\mathrm{P}_{3}$ and $\mathrm{U}_{5}$, i.e., between $\sim 1340$ and $1295{ }^{\circ} \mathrm{C}$. The temperature can be delimited a little bit more in that in alloy $\mathrm{Co}-9.8 \mathrm{Al}-26.1 \mathrm{Nb}$ the peritectic reaction $\mathrm{L}+C 36 \leftrightarrow \mathrm{NbCo}_{2} \mathrm{Al}$ was observed at $1324{ }^{\circ} \mathrm{C}$ by DTA (Table 2), i.e., the temperature of $\mathrm{U}_{4}$ must lie between 1324 and $\sim 1340{ }^{\circ} \mathrm{C}\left(\mathrm{P}_{3}\right)$. The invariant reaction $\mathrm{U}_{5}$ is observed in alloys Co-26.1Al-15.6Nb (Fig. 1b), Co-9.4Al-28.2Nb,
$\mathrm{Co}-9.8 \mathrm{Al}-26.1 \mathrm{Nb}$ and $\mathrm{Co}-10.0 \mathrm{Al}-25.5 \mathrm{Nb}$ but in the latter three only on second heating (Table 2). For the alloy Co-26.1Al-15.6Nb the compositions of the three solid phases that take part in reaction $\mathrm{U}_{5}$ have been analysed by EPMA (Table 2).

The Heusler phase $\mathrm{NbCo}_{2} \mathrm{Al}^{[4]}$ is the only ternary compound that exists in the $\mathrm{Co}-\mathrm{Al}-\mathrm{Nb}$ system. It forms by the peritectic reaction $\mathrm{P}_{2}: \mathrm{L}+C 14+\mathrm{CoAl} \leftrightarrow \mathrm{NbCo}_{2} \mathrm{Al}$ at about $1485^{\circ} \mathrm{C}$. The composition of $\mathrm{P}_{2}$ can only be estimated from the compositions determined for the eutectic $\mathrm{L} \leftrightarrow C 14+\mathrm{CoAl}$ in the as-cast alloys Co-34.4Al-25.4Nb and $\mathrm{Co}-39.7 \mathrm{Al}-15.9 \mathrm{Nb}$ and the temperature of $\mathrm{P}_{2}$ has to be slightly lower than the eutectic temperatures measured in those two alloys which are 1494 and $1493{ }^{\circ} \mathrm{C}$, respectively (Table 2). The monovariant reaction $\mathrm{L} \leftrightarrow C 14+\mathrm{CoAl}$ has a maximum $\left(\mathrm{M}_{3}\right)$ at about $1520{ }^{\circ} \mathrm{C}$. The temperature is again estimated from the temperatures determined for $\mathrm{L} \leftrightarrow$ $\mathrm{C} 14+\mathrm{CoAl}$ in alloys Co-34.4Al-25.4Nb and Co-39.7Al$15.9 \mathrm{Nb}$ and the presumable course of the isotherms. According to Alkemade's theorem the position of the maximum should be at the intersection of the monovariant line with the line that connects the congruent melting points of $C 14$ and CoAl (Alkemade line). Because the congruent composition of $\mathrm{C} 14$ is not exactly known, the composition of the maximum $\mathrm{M}_{3}$ - as well as those of $\mathrm{M}_{1}$ and $\mathrm{M}_{2}$ - can not be exactly determined. The latter two maxima are also observed for the monovariant reactions involving the $C 14$ Laves phase, namely at about $1650{ }^{\circ} \mathrm{C}$ on $\mathrm{L}+C 14+$ $\mathrm{NbAl}_{3}\left(\mathrm{M}_{2}\right)$ and at about $1640{ }^{\circ} \mathrm{C}$ on $\mathrm{L}+C 14+\mathrm{Nb}_{2} \mathrm{Al}$ $\left(\mathrm{M}_{1}\right)$. In between these maxima is the ternary eutectic $\mathrm{E}_{1}$ : $\mathrm{L} \leftrightarrow C 14+\mathrm{Nb}_{2} \mathrm{Al}+\mathrm{NbAl}_{3}$ at $1553{ }^{\circ} \mathrm{C}$ which has been observed in alloy Co-66.1 Al-32.8Nb (Fig. 1d). In this alloy $\mathrm{NbAl}_{3}$ solidified first followed by a small amount of twophase $\mathrm{NbAl}_{3}+C 14$ before finally the ternary eutectic $\mathrm{Cl} 14+\mathrm{Nb}_{2} \mathrm{Al}+\mathrm{NbAl}_{3}$ with a composition of $2.8 \mathrm{Co}, 55.1$ $\mathrm{Al}, 42.1 \mathrm{Nb}$ solidified (Fig. 1d, 2). It is noted that a comparable eutectic $C 14+\mathrm{Nb}_{2} \mathrm{Al}+\mathrm{NbAl}_{3}$ exists at about the same composition $(2.4 \mathrm{Ni}, 57.2 \mathrm{Al}, 40.4 \mathrm{Nb})$ and temperature $\left(1553.6^{\circ} \mathrm{C}\right)$ in the $\mathrm{Ni}-\mathrm{Al}-\mathrm{Nb}$ system. ${ }^{[19]}$

In the Al-rich part two more U-type reactions were observed. At $1322{ }^{\circ} \mathrm{C}$ the invariant reaction $\mathrm{U}_{3}$ : $\mathrm{L}+C 14 \leftrightarrow$ $\mathrm{NbAl}_{3}+\mathrm{CoAl}$ takes place (alloys Co-60.0Al-25.0Nb, Co60.0Al-23.0Nb, Co-68.5Al-10.6Nb). In alloy Co-68.5$\mathrm{Al}-10.6 \mathrm{Nb}$ an additional signal is observed at $1174{ }^{\circ} \mathrm{C}$ which is associated with the invariant reaction $\mathrm{U}_{6}$ : $\mathrm{L}+\mathrm{CoAl} \leftrightarrow \mathrm{NbAl}_{3}+\mathrm{Co}_{2} \mathrm{Al}_{5}$. This temperature is exactly the same that has been determined by Subramanian and Simmons ${ }^{[12]}$ for $\mathrm{U}_{6}$. It is noted that the two alloys which contain the $C 14$ Laves phase with the highest Al content (alloys Co-60.0Al-25.0Nb and Co-60.0Al-23.0Nb) show a small but distinct additional first order signal at about $1495{ }^{\circ} \mathrm{C}$ which can not be allocated to any reaction (marked "?" in Table 2).

According to the reaction scheme in Fig. 4, three more invariant reactions $\left(\mathrm{U}_{1}, \mathrm{U}_{2}\right.$, and $\left.\mathrm{P}_{1}\right)$ take place in the $\mathrm{Nb}$-rich part of the system whose temperatures can only be given tentatively because they are difficult to determine experimentally. These difficulties are twofold. First of all it is difficult to produce homogeneous alloys because of the very high melting point of $\mathrm{Nb}$ and actually the alloys 

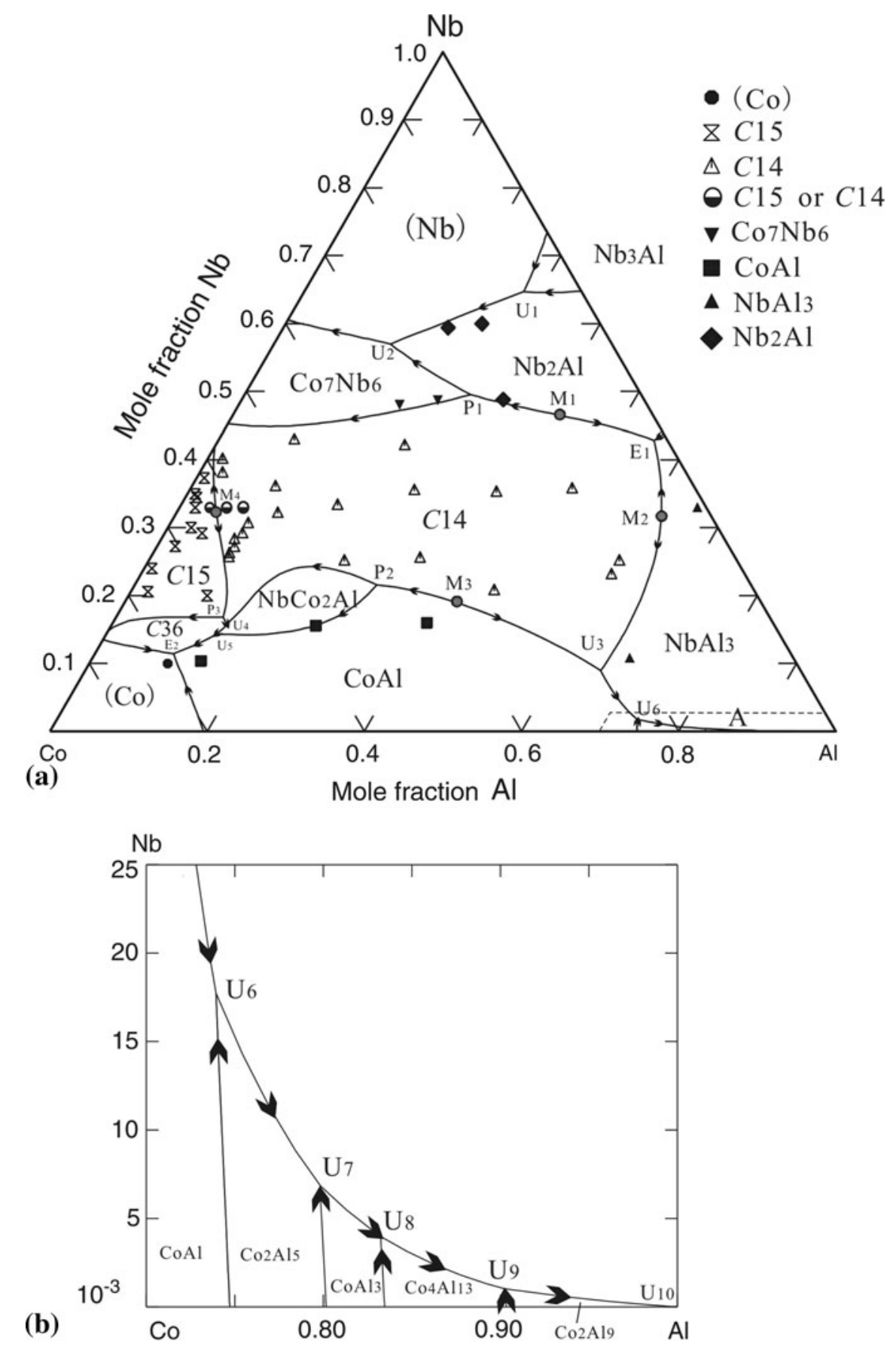

Fig. 3 (a) Calculated liquidus projection of the Co-Al-Nb system. (b) Enlarged area "A" of a showing the invariant points $U_{6}-U_{10}$ in the Al-rich corner of the Co-Al-Nb system

Co-21.0Al-59.4Nb and Co-25.0Al-60.0Nb were not homogeneous but showed a significant enrichment in $\mathrm{Nb}$ in some parts which resulted from incomplete dissolution of $\mathrm{Nb}$ during melting. Secondly, in some of the Nb-rich alloys an additional phase was observed which has about the same $\mathrm{Nb}$ content as the $\mu$ phase, i.e., 48 at.\%, but much lower $\mathrm{Al}$ contents. Though it was not possible to establish its structure by XRD because the volume fraction of this phase was always small, it is inferred that the phase might have the $\mathrm{Ti}_{2} \mathrm{Ni}$ structure. A phase of this structure type is frequently observed in - particularly slow cooled-Fe- $\mathrm{Nb}$ alloys and it has been demonstrated that this phase is stabilised by minor amounts of impurities, especially of phosphorous and sulphur. ${ }^{[20]}$ Whether this is the same phase that had been identified earlier as $\mu^{\prime}$ is open to speculation. The presence of this phase is presumably responsible for additional DTA 


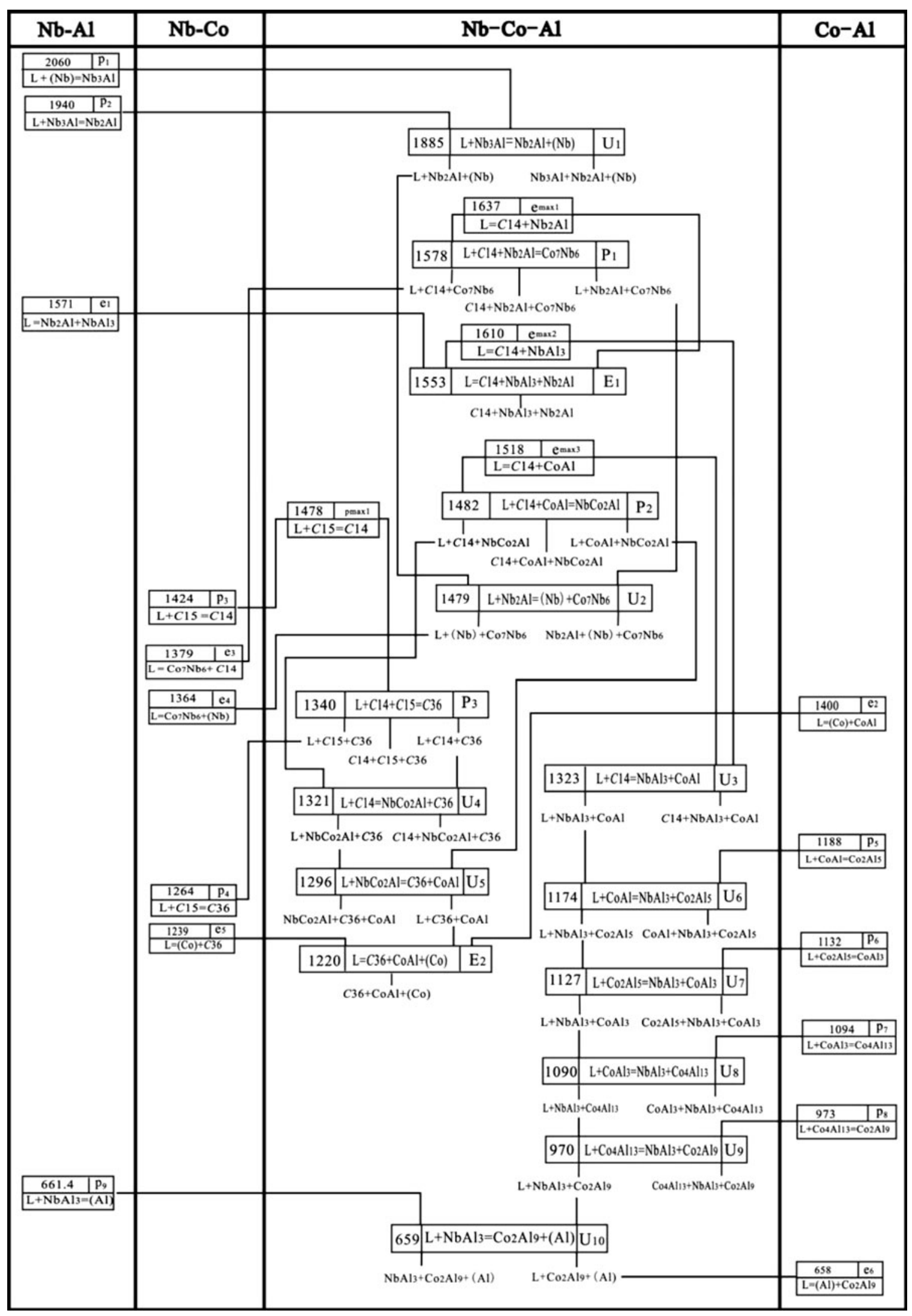

Fig. 4 Calculated reaction scheme for the liquidus of the Co-Al-Nb system. Monotectic equilibria not any longer containing the liquid are underlined 
signals in the Nb-rich alloys Co-20.4Al-48.3Nb, Co-24.2Al$42.0 \mathrm{Nb}$, and $\mathrm{Co}-24.9 \mathrm{Al}-48.9 \mathrm{Nb}$.

The ternary peritectic reaction $\mathrm{P}_{1}: \mathrm{L}+\mathrm{Nb}_{2} \mathrm{Al}+C 14 \leftrightarrow$ $\mathrm{Co}_{7} \mathrm{Nb}_{6}$ by which the $\mu$ phase forms may take place at $1578{ }^{\circ} \mathrm{C}$. The alloy $\mathrm{Co}-33.3 \mathrm{Al}-48.8 \mathrm{Nb}$ shows two reactions below the melting, one at $1595{ }^{\circ} \mathrm{C}$ which is presumably associated with the eutectic reaction $\mathrm{L} \leftrightarrow C 14+\mathrm{Nb}_{2} \mathrm{Al}$ and a second one at $1578{ }^{\circ} \mathrm{C}$, which presumably is associated with $\mathrm{P}_{1}$. However, because the composition of the alloy is apparently close to that of $\mathrm{P}_{1}$ the microstructure is difficult to interpret. The microstructure of alloy Co-33.3Al-48.8Nb (Fig. 1e) is composed of a small volume fraction of primary $\mathrm{Nb}_{2} \mathrm{Al}$, the eutectic $\mathrm{Nb}_{2} \mathrm{Al}+C 14$ and $\mathrm{Co}_{7} \mathrm{Nb}_{6}$. Along the monovariant line $\mathrm{e}_{3}-\mathrm{P}_{1}$ the type of the reaction for $\mathrm{L}+C 14+\mathrm{Co}_{7} \mathrm{Nb}_{6}$ changes from eutectic in the binary to peritectic.
Compositions and temperatures of the invariant reactions $\mathrm{U}_{1}: \mathrm{L}+\mathrm{Nb}_{3} \mathrm{Al} \leftrightarrow \mathrm{Nb}_{2} \mathrm{Al}+(\mathrm{Nb})$ and $\mathrm{U}_{2}: \mathrm{L}+\mathrm{Nb}_{2} \mathrm{Al} \leftrightarrow$ $(\mathrm{Nb})+\mathrm{Co}_{7} \mathrm{Nb}_{6}$ were not established by the experiments. The existence of these reactions has been established by the Thermo-Calc calculations (see following paragraph). However, it may be possible that the DTA signal observed at $1476{ }^{\circ} \mathrm{C}$ in the alloy $\mathrm{Co}-21.0 \mathrm{Al}-59.4 \mathrm{Nb}$ may be associated with reaction $\mathrm{U}_{2}$ (calculated temperature: $1479{ }^{\circ} \mathrm{C}$ ).

All experimental results were finally used to optimize the thermodynamic parameters of each phase in the $\mathrm{Co}-\mathrm{Al}-\mathrm{Nb}$ system by CALPHAD modelling with the aid of the Thermo-Calc software package (Table 3). Based on the present thermodynamic description, the liquidus projection was calculated and a reaction scheme has been established (Fig. 3 and 4). Comparison of the experimentally determined (Fig. 2b) and calculated liquidus projection (Fig. 3)

Table 3 Models used for the CALPHAD modeling for the phases in the Co-Al-Nb system

\begin{tabular}{|c|c|c|}
\hline Phase & Model in binary system & Model in Co-Al-Nb system \\
\hline Liquid & $(\mathrm{Co}, \mathrm{Nb})$ & $(\mathrm{Al}, \mathrm{Co}, \mathrm{Nb})$ \\
\hline$(\mathrm{Nb})$ & $(\mathrm{Co}, \mathrm{Nb}, \mathrm{Va}) 1 \mathrm{Va} 3$ & $(\mathrm{Al}, \mathrm{Co}, \mathrm{Nb}, \mathrm{Va}) 1 \mathrm{Va} 3$ \\
\hline CoAl & $(\mathrm{Al}, \mathrm{Co}, \mathrm{Va}) 0.5(\mathrm{Al}, \mathrm{Co}, \mathrm{Va}) 0.5 \mathrm{Va} 3$ & $(\mathrm{Al}, \mathrm{Co}, \mathrm{Nb}, \mathrm{Va}) 0.5(\mathrm{Al}, \mathrm{Co}, \mathrm{Nb}, \mathrm{Va}) 0.5 \mathrm{Va} 3$ \\
\hline (Co) & $(\mathrm{Al}, \mathrm{Co}, \mathrm{Nb}) \mathrm{Va}$ & $(\mathrm{Al}, \mathrm{Co}, \mathrm{Nb}) \mathrm{Va}$ \\
\hline Laves C15 & $(\mathbf{C o}, \mathrm{Nb}) 2(\mathrm{Co}, \mathbf{N b})$ & $(\mathrm{Al}, \mathrm{Co}, \mathrm{Nb}) 2(\mathrm{Al}, \mathrm{Co}, \mathbf{N b})$ \\
\hline Laves C14 & $(\mathbf{C o}, \mathrm{Nb}) 2(\mathrm{Co}, \mathbf{N b})$ & $(\mathrm{Al}, \mathrm{Co}, \mathrm{Nb}) 2(\mathrm{Al}, \mathrm{Co}, \mathbf{N b})$ \\
\hline Laves C36 & $(\mathbf{C o}, \mathrm{Nb}) 2(\mathrm{Co}, \mathrm{Nb})$ & $(\mathrm{Al}, \mathrm{Co}, \mathrm{Nb}) 2(\mathrm{Al}, \mathrm{Co}, \mathbf{N b})$ \\
\hline $\mathrm{Co}_{7} \mathrm{Nb}_{6}(\mu)$ & $\mathrm{Co}(\mathrm{Co}, \mathrm{Nb}) 2 \mathrm{Nb} 4(\mathbf{C o}, \mathrm{Nb}) 6$ & $\mathrm{Co}(\mathrm{Co}, \mathrm{Nb}) 2 \mathrm{Nb} 4(\mathrm{Al}, \mathrm{Co}, \mathrm{Nb}) 6$ \\
\hline $\mathrm{Nb}_{3} \mathrm{Al}$ & $(\mathbf{N b})_{3}(\mathrm{Al}, \mathrm{Nb})$ & $(\mathrm{Co}, \mathrm{Nb})_{3}(\mathrm{Al}, \mathrm{Co}, \mathrm{Nb})$ \\
\hline $\mathrm{Nb}_{2} \mathrm{Al}$ & $(\mathbf{A l}, \mathrm{Nb}) 5 \mathrm{Nb} 2(\mathrm{Al}, \mathbf{N b}) 8$ & $(\mathrm{Al}, \mathrm{Co}, \mathrm{Nb}) 5 \mathrm{Nb} 2(\mathrm{Al}, \mathrm{Co}, \mathbf{N b}) 8$ \\
\hline $\mathrm{NbCO}_{2} \mathrm{Al}$ & $\cdots$ & $(\mathbf{A l}, \mathrm{Nb}) \mathrm{Co} 2(\mathrm{Al}, \mathrm{Co}, \mathbf{N b})$ \\
\hline
\end{tabular}

Table 4 Comparison between the calculated $\left(T_{\text {Calc. }}\right)$ and measured $\left(T_{\text {DTA }}\right)$ temperatures for the various invariant reactions in the $\mathrm{Co}-\mathrm{Al}-\mathrm{Nb}$ system

\begin{tabular}{|c|c|c|c|c|}
\hline Invariant reaction & Type & Label & $T_{\text {Calc. }}{ }^{\circ} \mathrm{C}$ & $T_{\text {DTA }},{ }^{\circ} \mathrm{C}$ \\
\hline $\mathrm{L}+\mathrm{Nb}_{3} \mathrm{Al} \leftrightarrow \mathrm{Nb}_{2} \mathrm{Al}+(\mathrm{Nb})$ & Transition & $\mathrm{U}_{1}$ & 1885 & n.d. \\
\hline $\mathrm{L} \leftrightarrow C 14+\mathrm{Nb}_{2} \mathrm{Al}$ & Maximum & $\mathrm{M}_{1}$ & 1637 & $\sim 1640$ \\
\hline $\mathrm{L} \leftrightarrow C 14+\mathrm{NbAl}_{3}$ & Maximum & $\mathrm{M}_{2}$ & 1610 & $\sim 1650$ \\
\hline $\mathrm{L}+\mathrm{Nb}_{2} \mathrm{Al}+C 14 \leftrightarrow \mathrm{Co}_{7} \mathrm{Nb}_{6}$ & Peritectic & $\mathrm{P}_{1}$ & 1578 & 1578 \\
\hline $\mathrm{L} \leftrightarrow C 14+\mathrm{Nb}_{2} \mathrm{Al}+\mathrm{NbAl}_{3}$ & Eutectic & $\mathrm{E}_{1}$ & 1553 & 1553 \\
\hline $\mathrm{L} \leftrightarrow C 14+\mathrm{CoAl}$ & Maximum & $\mathrm{M}_{3}$ & 1518 & $\sim 1520$ \\
\hline $\mathrm{L}+C 14+\mathrm{CoAl} \leftrightarrow \mathrm{NbCo}_{2} \mathrm{Al}$ & Peritectic & $\mathrm{P}_{2}$ & 1482 & 1485 \\
\hline $\mathrm{L}+\mathrm{Nb}_{2} \mathrm{Al} \leftrightarrow(\mathrm{Nb})+\mathrm{Co}_{7} \mathrm{Nb}_{6}$ & Transition & $\mathrm{U}_{2}$ & 1479 & $1476(?)$ \\
\hline $\mathrm{L}+C 15 \leftrightarrow C 14$ & Maximum & $\mathrm{M}_{4}$ & 1478 & $\sim 1475$ \\
\hline $\mathrm{L}+C 15+C 14 \leftrightarrow C 36$ & Peritectic & $\mathrm{P}_{3}$ & 1340 & $\sim 1340$ \\
\hline $\mathrm{L}+C 14 \leftrightarrow \mathrm{NbAl}_{3}+\mathrm{CoAl}$ & Transition & $\mathrm{U}_{3}$ & 1323 & 1322 \\
\hline $\mathrm{L}+C 14 \leftrightarrow C 36+\mathrm{NbCo}_{2} \mathrm{Al}$ & Transition & $\mathrm{U}_{4}$ & 1321 & $\sim 1330$ \\
\hline $\mathrm{L}+\mathrm{NbCo}_{2} \mathrm{Al} \leftrightarrow \mathrm{CoAl}+C 36$ & Transition & $\mathrm{U}_{5}$ & 1296 & 1295 \\
\hline $\mathrm{L} \leftrightarrow(\mathrm{Co})+\mathrm{CoAl}+C 36$ & Eutectic & $\mathrm{E}_{2}$ & 1220 & 1220 \\
\hline $\mathrm{L}+\mathrm{CoAl} \leftrightarrow \mathrm{NbAl}_{3}+\mathrm{Co}_{2} \mathrm{Al}_{5}$ & Transition & $\mathrm{U}_{6}$ & 1174 & 1174 \\
\hline
\end{tabular}

Temperatures in italics have not been directly measured by DTA but have been derived from the course of the isotherms or as detailed in the text; n.d. not determined 
shows that the experimentally determined liquidus projection is well described by the calculated one. The four maxima $\mathrm{M}_{1}-\mathrm{M}_{4}$, whose existence was deduced from the experiments, are confirmed by the calculation. Also the temperatures for the maxima fit quite nicely. Only for $\mathrm{M}_{2}$ a larger difference is observed $\left(1610^{\circ} \mathrm{C}\right.$ vs. $\sim 1650{ }^{\circ} \mathrm{C}$; Table 4$)$ presumably due to the few experimental data. While most of the primary phases are well accounted for by the modelling, there is some difference in the extension of the primary $\mathrm{NbCo}_{2} \mathrm{Al}$ phase region. Again this difference is caused by the lack of experimental data in this composition range.

In Table 4 the calculated temperatures for the invariant reactions are compared with the experimentally determined ones and they are in good agreement as the difference is only $5{ }^{\circ} \mathrm{C}$ or less for all the invariant reaction temperatures that have been determined by DTA. The calculated temperatures of the invariant reactions $\mathrm{U}_{1}$ and $\mathrm{U}_{2}$, which both have not been determined experimentally, are 1885 and $1479{ }^{\circ} \mathrm{C}$, respectively. However, the actual temperatures of these two invariant reactions could differ substantially from the calculated ones because in this $\mathrm{Nb}$-rich part of the system the calculation is not supported by any experimental data.

\section{Summary}

A partial liquidus projection for the Co-Al-Nb system has been experimentally determined for the first time. The experimental data were then used to optimise the thermodynamic description of all phases based on which a liquidus projection and a reaction scheme have been calculated by the CALPHAD method using the Thermo-Calc program. In the investigated range of compositions, which excludes the $\mathrm{Al}$ corner of the system at $\mathrm{Al}$ contents $>80$ at. $\% \mathrm{Al}$, eleven invariant reactions were identified. The prominent features of the liquidus projection are the extended fields of primary crystallisation of the $\mathrm{Co}-\mathrm{Nb}$ phases. By the addition of $\mathrm{Al}$ the melting temperature of $C 14$ increases from $1424{ }^{\circ} \mathrm{C}$ in the binary $\mathrm{Co}-\mathrm{Nb}$ system to about $1700{ }^{\circ} \mathrm{C}$, that of $\mathrm{Co}_{7} \mathrm{Nb}_{6}$ from $1424{ }^{\circ} \mathrm{C}$ to $1578{ }^{\circ} \mathrm{C}$ and that of $C 36$ from $1264{ }^{\circ} \mathrm{C}$ to $1340{ }^{\circ} \mathrm{C}$. The only exception is $C 15$, whose melting temperature decreases slightly from $1485{ }^{\circ} \mathrm{C}$ to $1475{ }^{\circ} \mathrm{C}$ by alloying with $\mathrm{Al}$. The only ternary compound, the Heusler phase $\mathrm{NbCo}_{2} \mathrm{Al}$, melts incongruently with a maximum temperature of $1485^{\circ} \mathrm{C}$.

\section{Acknowledgments}

The authors would like to thank Mr. R. Staegemann, Mr. M. Kulse, and Mr. S. Voß for the preparation of the alloys, Mr. G. Bialkowski for EDM preparation of the samples, Mrs. H. Bögershausen for preparation of the metallographic sections, and Mrs. I. Wossack for EPMA. The authors are also indebted to Dr. N. Dupin for letting us use her adjusted thermodynamic parameters for Co-Al. Financial support by the Max Planck Society within the framework of the inter-institutional research initiative "The Nature of Laves Phases" is gratefully acknowledged.

\section{References}

1. K.C. Hari Kumar, I. Ansara, P. Wollants, and L. Delaey, Thermodynamic Optimisation of the Co-Nb System, J. Alloys Compd., 1998, 267, p 105-112

2. F. Stein, D. Jiang, M. Palm, G. Sauthoff, D. Grüner, and G. Kreiner, Experimental Reinvestigation of the $\mathrm{Co}-\mathrm{Nb}$ Phase Diagram, Intermetallics, 2008, 16(6), p 785-792

3. B. Grushko and T.Ya. Velikanova, Formation of Quasicrystals and Related Structures in Systems of Aluminum with Transition Metals. I. Binary Systems Formed by Aluminum with $3 d$ Metals, Powder Metall. Met. Ceram., 2004, 43(1-2), p 72-86

4. V.Ya. Markiv, Yu.V. Voroshilov, P.I. Kripyakevich, and E.E. Cherkasin, New Compounds of the $\mathrm{MnCu}_{2} \mathrm{Al}$ and $\mathrm{MgZn}_{2}$ Types Containing Al and Ga, Kristallografiya, 1964, 9(5), p 737-738, in Russian; TR: Sov. Phys. Crystallogr. 1965, 9, p $619-620$

5. V.V. Burnashova, V.R. Ryabov, and V.Ya. Markiv, Investigation of Nb-Fe-Al and Nb-Co-Al Systems, Dopov. Akad. Nauk Ukr. RSR Ser. A: Fiz. Tekhn. Mat. Nauki, 1970, 1970(8), p 747750, in Ukrainian

6. O. Dovbenko, F. Stein, M. Palm, and O. Prymak, Experimental Determination of the Ternary Co-Al-Nb Phase Diagram, Intermetallics, 2010, 18(11), p 2191-2207

7. C.R. Hunt and A. Raman, Alloy Chemistry of $\sigma(\beta \mathrm{U})$-Related Phases, Z. Metallkde, 1968, 59(9), p 701-707

8. A.C. Neiva, Aluminium-Cobalt-Niobium, Ternary Alloys, vol. 4, G. Petzow and G. Effenberg, Eds., VCH, Weinheim, 1991, p 229-232

9. P. Villars, A. Prince, and H. Okamoto, Al-Co-Nb, Handbook of Ternary Alloy Phase Diagrams, vol. 3, ASM International, Materials Park, 1995, p 3048-3052

10. L.N. Nesterovich, G.V. Kupchenko, N.P. Ivanov, and L.N. Shpakovskaya, Investigation of the Structure of Monovariant Directionally Crystallised Cobalt-Aluminium-Niobium Eutectics, Fiz. Met. Metalloved., 1978, 46(1), p 221-224, in Russian; TR: Phys. Met. Metallogr. (USSR), 1978, 46(1), p 198-201

11. G. Haour, F. Mollard, B. Lux, and I.G. Wright, New Eutectics Based on Fe, Co, and Ni-II. Co-Base Eutectics, Z. Metallkde, 1978, 69(2), p 69-74

12. P.R. Subramanian and J.P. Simmons, Phase Equilibria in the Vicinity of the $\mathrm{DO}_{22} \mathrm{Al}_{3} \mathrm{Nb}$ Composition in the Al-Nb-W, Al-Nb-Co, Al-Nb-Pt, and Al-Nb-Ag Systems, Scr. Met. Mat., 1991, 25(1), p 231-236

13. V.T. Witusiewicz, A.A. Bondar, U. Hecht, and T.Ya. Velikanova, The Al-Nb-Ti System-IV. Experimental Study and Thermodynamic Re-evaluation of the Binary Al-Nb and Ternary Al-NbTi Systems, J. Alloys Compd., 2009, 472, p 133-161

14. N. Dupin and I. Ansara, Evaluation thermodynamique du systeme Al-Co, Rev. Metall., 1998, 9, p 1121-1129

15. C. He, F. Stein, M. Palm, and D. Raabe, Thermodynamic Re-assessment of the Co-Nb System, Mat. Res. Soc. Symp. Proc., 2009, 1128, p 239-244

16. A.J. McAllister, The Al-Co System, Bull. Alloy Phase Diag., 1989, 10(6), p 646-650

17. U.R. Kattner, Al-Nb (Aluminum-Niobium), Binary Alloy Phase Diagrams, 2nd ed., T.B. Massalski, Ed., ASM International, Materials Park, 1990, p 179-181

18. A. von Keitz, G. Sauthoff, and P. Neumann, Laves Phases for High Temperatures - Structure, Stability and Constitution, Z. Metallkde, 1998, 89(12), p 803-810

19. C. Triveno Rios, S. Milenkovic, and R. Caram, A Novel Ternary Eutectic in the Nb-Al-Ni System, Scr. Mater., 2003, 48(10), p 1495-1500

20. C.G. Schön and J.A.S. Tenório, The Chemistry of the IronNiobium Intermetallics, Intermetallics, 1996, 4(3), p 211-216 